\title{
Recent developments in design and synthesis of well-defined ruthenium metathesis catalysts - a highly successful opening for intricate organic synthesis
}

\author{
Ileana Dragutan,* Valerian Dragutan,* and Petru Filip \\ Institute of Organic Chemistry, 202B Spl. Independentei, POB 35-108, \\ Bucharest 060023, Romania \\ E-mail: idragutan@yahoo.com \& vdragutan@yahoo.com
}

\begin{abstract}
Dedicated to Professor Alexandru T. Balaban on the occasion of his $75^{\text {th }}$ birthday anniversary, in acknowledgement of his significant contribution to advancement in theoretical and synthetic organic chemistry

(received 03 Jan 05; accepted 28 Mar 05; published on the web 08 Apr 05)
\end{abstract}

\begin{abstract}
This paper surveys the latest and fast growing developments in the design and synthesis of homogeneous and immobilized ruthenium metathesis catalysts. These novel ruthenium carbene complexes, devised as convenient counterparts of the well-defined tungsten and molybdenum alkylidene complexes, display comparable activity and selectivity in metathesis reactions combined with good tolerance towards organic functionalities, air and moisture. Due to their valuable attributes, they have been applied successfully in a multitude of complex organic and polymer syntheses involving ring-opening and ring-closing metathesis reactions, crossmetathesis, enyne metathesis and ring-opening metathesis polymerization.
\end{abstract}

Keywords: Ruthenium metathesis catalysts, N-heterocyclic carbenes, ruthenium carbene complexes, immobilized ruthenium complexes, ring-closing metathesis, ring-opening metathesis polymerization

\section{Contents}

1. Introduction

2. Ruthenium alkylidene complexes

3. Ruthenium vinylidene complexes

4. Ruthenium indenylidene complexes

5. Ruthenium allenylidene complexes

6. Miscellaneous ruthenium complexes 
7. Immobilized ruthenium complexes

8. Conclusions

9. References

\section{Introduction}

During the last decade, olefin metathesis has known a real breakthrough, becoming a powerful synthetic tool in organic and polymer chemistry. ${ }^{1,2}$ Along these lines, numerous ruthenium complexes, as convenient counterparts of the well-defined tungsten and molybdenum alkylidene complexes, ${ }^{3,4}$ have been prepared and used successfully as efficient metathesis catalyst precursors in a wide range of well-established synthetic procedures such as ring-closing metathesis (RCM) (Eq.1), ${ }^{5}$ ring-opening metathesis (ROM) (Eq.2), ${ }^{5}$ cross-metathesis (CM) (Eq.3), ${ }^{6}$ enyne metathesis (EM) (Eq.4), ${ }^{7}$ acyclic diene metathesis (ADMET) (Eq.5) ${ }^{8}$ and ringopening metathesis polymerization (ROMP) (Eq.6) ${ }^{9}$.
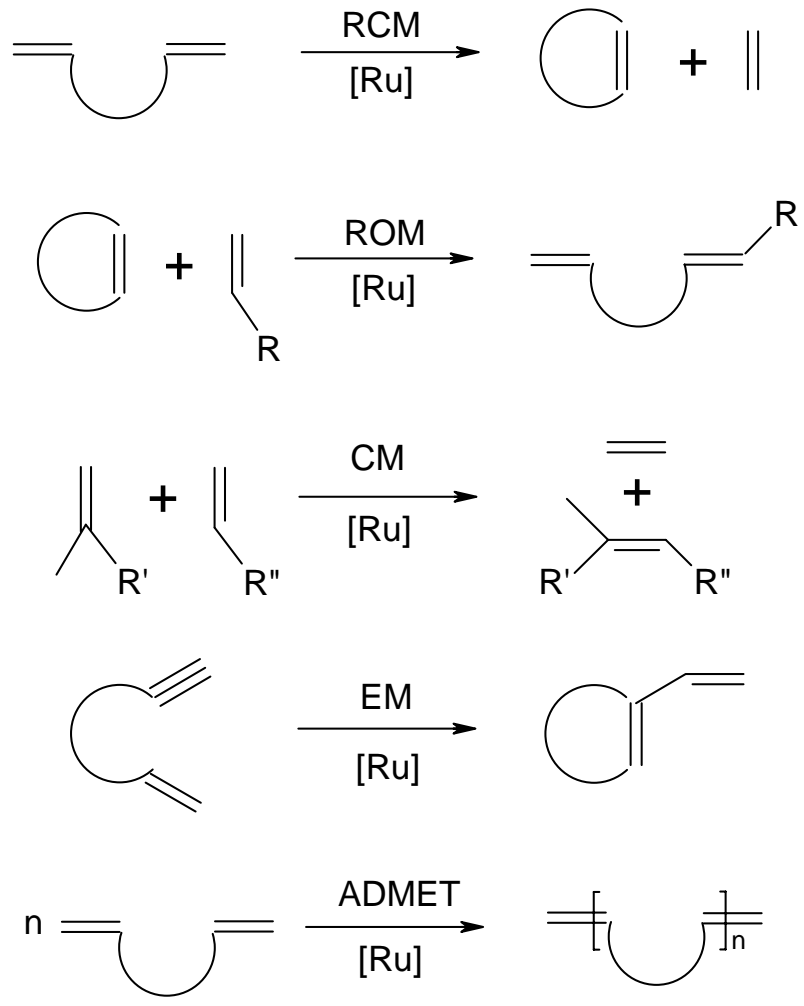

$\mathrm{n}$

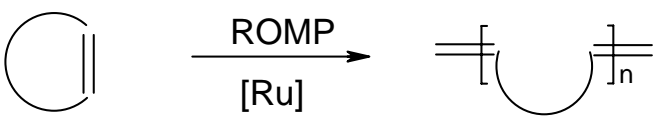


Due to the ever increasing potential of these methodologies, new applications have emerged in manufacturing a diversity of natural products, biologically active organic compounds or functional polymers with special architectures. ${ }^{10}$

\section{Ruthenium alkylidene complexes}

The well-defined ruthenium-carbene complexes $\mathbf{1}$ and 2, reported by Grubbs and coworkers, ${ }^{11,12}$ are the first ruthenium catalysts to show good activity and selectivity in metathesis of acyclic and cyclic olefins while exhibiting an improved tolerance towards various organic functionalities, air and moisture, opening, thus, a new era in metathesis applications in organic and polymer syntheses $^{13-17}$ (Scheme 1, where $\mathrm{R}$ is isopropyl, phenyl, cyclopentyl or cyclohexyl (Cy) and $\mathrm{R}^{\prime}$ is methyl or phenyl).<smiles>[R5]C(c1ccccc1)[R]([R5])([R5])Cl</smiles>

1<smiles>[R]C([R])=CC([R5])=[R]([R5])([R5])Cl</smiles>

2

$$
\mathrm{R}=i-\mathrm{Pr}, \mathrm{Ph}, \mathrm{C}_{5} \mathrm{H}_{9}, \mathrm{Cy} \quad \mathrm{R}=\mathrm{Ph}, \mathrm{C}_{5} \mathrm{H}_{9}, \mathrm{Cy}
$$

Scheme 1. Well-defined ruthenium benzylidene and vinylcarbene initiators.

Success recorded with 1 and $\mathbf{2}$ fueled an impetus for the design and preparation of an array of ruthenium alkylidene complexes and their application, by many research teams, as a sustainable strategy for the synthesis of libraries of organic compounds and polymeric materials. ${ }^{18-21}$ An important group of catalysts, therein, consists of ruthenium alkylidene complex 3 , bearing a heteroatom-containing carbene, as well as the chelated complexes $\mathbf{4}$ and $\mathbf{5}$ developed by Ciba $\mathrm{AG},{ }^{18,19}$ complex 6 reported by $\mathrm{Abele}^{20}$ and 7 reported by $\mathrm{Mol}^{21}$ (Scheme 2, where $\mathrm{R}$ is $\mathrm{H}, \mathrm{CH}_{3}$; $\mathrm{R}^{\prime}$ is $\mathrm{CH}_{3}, \mathrm{C}_{6} \mathrm{H}_{5} ; \mathrm{R}^{\prime \prime}$ is an alkyl group).<smiles>CCCP(Cl)(Cl)(CSc1ccccc1)CC(C)C</smiles>

3

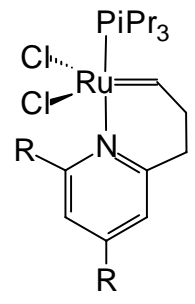

4

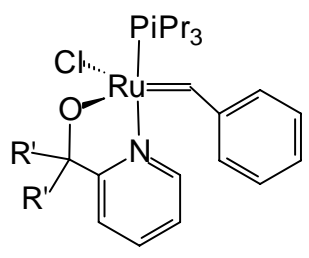

5

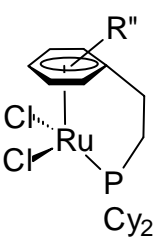

6

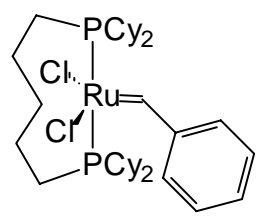

7

Scheme 2. Well-defined ruthenium alkylidene metathesis catalysts. 
A practical advantage offered by these new ruthenium catalysts is that, for the first time, it became possible to use such Ru initiators in ROMP of cycloolefins (e.g. dicyclopentadiene) with the reaction injection molding (RIM) technique, and by immobilization on solid supports. Furthermore, their synthesis is a convenient one-step procedure starting from the ruthenium phosphane benzylidene complex $\mathbf{1}$. For instance, reaction of two equivalents of complex 1 with one equivalent of phenyl vinyl sulphide affords the ruthenium complex 3, with an S-containing ligand, whereas an equimolar reaction between 1 and 2-(3-butenyl)pyridine leads to the chelated ruthenium complex 4 . Likewise, bidentate phosphines with large natural bite angles (e.g. based on xanthene or $\left.\mathrm{Cy}_{2} \mathrm{P}\left(\mathrm{CH}_{2}\right)_{\mathrm{n}} \mathrm{PCy}_{2}, \mathrm{n}=3-5\right)$ have been obtained from ruthenium complex 1 and 1, $\omega$ bis(dicyclohexylphosphine)alkanes (e.g. 1,5-bis(dicyclohexylphosphine)pentane). ${ }^{21}$ The latter bidentate phosphine ligands could also be used to attach ruthenium alkylidene complexes to solid supports as a means of obtaining heterogenized catalysts.

To finely tune the activity and stability of the ruthenium alkylidene complexes, further heterocyclic ligands have been incorporated into the ruthenium coordination sphere. Complexes $8(\mathrm{R}=\mathrm{Cy})$ and $\mathbf{9}\left(\mathrm{R}=\right.$ Mes, $\left.\mathrm{R}^{\prime}=\mathrm{H}, \mathrm{Br}, \mathrm{NO}_{2}\right)$ are representative examples. ${ }^{22,23}$

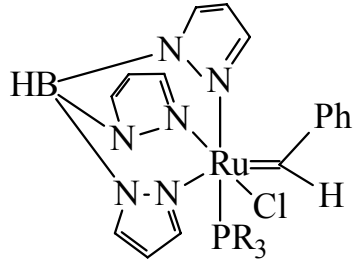

8

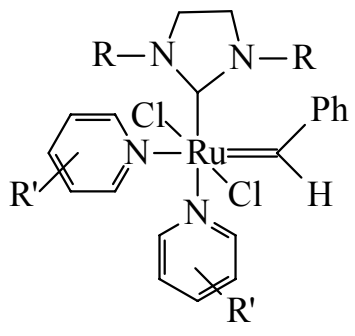

9

Scheme 3. Ruthenium benzylidene complexes with heterocyclic ligands.

Of these two complexes, the bis-pyridine adduct $9\left(\mathrm{R}^{\prime}=\mathrm{Br}\right)$ is an excellent metathesis catalyst possessing a high initiation rate.

Schiff-bases proved to be another class of attractive ligands in creating new ruthenium complexes. They incorporate two donor atoms ( $\mathrm{N}$ and $\mathrm{O}$ ) which, on chelation, provide opposite features: the phenolate oxygen atom is a hard donor and will stabilize a higher oxidation state of the ruthenium atom whereas the imine nitrogen is a softer donor and, consequently, will rather stabilize the lower oxidation state of ruthenium. Besides, Schiff-bases are easily accessible through one-step procedures via almost quantitative condensation of common amines with aldehydes. To capitalize on the high potential of Schiff-bases, a wide range of efficient ruthenium catalysts, e.g. 10a-f and 11a-f, with O,N-chelated Schiff-base "dangling-ligands", have been prepared by Verpoort and coworkers. ${ }^{24,25}$ 


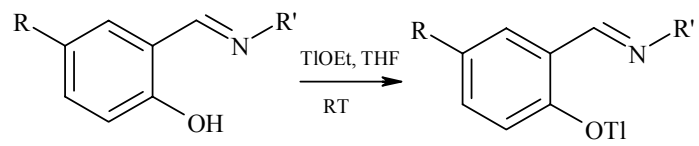

a: $\mathrm{R}=\mathrm{H}, \mathrm{R}^{\prime}=\mathrm{Me}$

b: $\mathrm{R}=\mathrm{NO}_{2}, \mathrm{R}^{\prime}=\mathrm{Me}$

c: $\mathrm{R}=\mathrm{H}, \mathrm{R}^{\prime}=2,6-\mathrm{Me}_{2}-4-\mathrm{BrC}_{6} \mathrm{H}_{2}$

d: $\mathrm{R}=\mathrm{NO}_{2}, \mathrm{R}^{\prime}=2,6-\mathrm{Me}_{2}-4-\mathrm{BrC}_{6} \mathrm{H}_{2}$

e: $R=H, R^{\prime}=2,6-i-\mathrm{Pr}_{2} \mathrm{C}_{6} \mathrm{H}_{3}$

f: $\mathrm{R}=\mathrm{NO}_{2}, \mathrm{R}^{\prime}=2,6-i-\mathrm{Pr}_{2} \mathrm{C}_{6} \mathrm{H}_{3}$
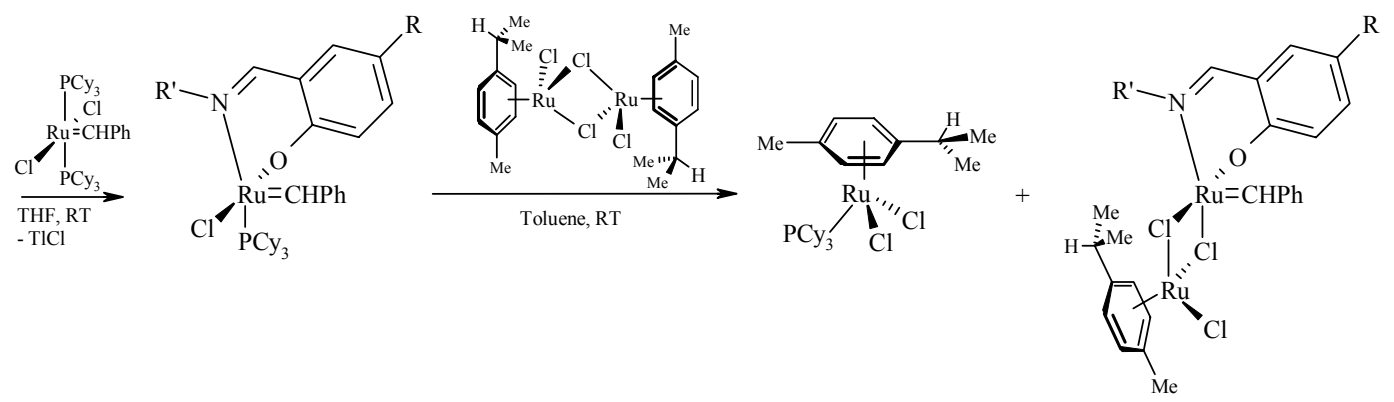

10

11

Scheme 4. Synthesis of Schiff-base ruthenium benzylidene complexes.

In addition, the same research group introduced cationic Ru-benzylidene complexes 12a-f prepared in situ from the corresponding neutral complexes 10a-f, by treatment with one equivalent of silver salts or trimethylsilyl salts (Scheme 5).

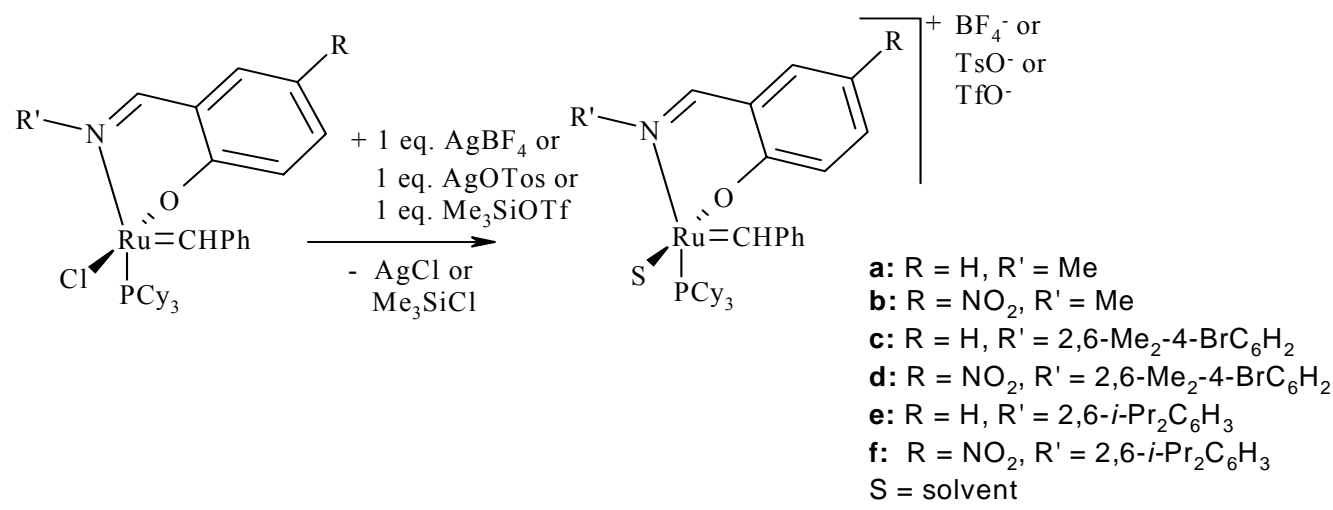

10

12

Scheme 5. Synthesis of cationic Schiff-base ruthenium complexes.

Schiff-base ligated ruthenium carbenes are appropriate scaffolds for manufacturing immobilized catalysts by means of spacers attached to a silylated solid support.

The portfolio of well-defined ruthenium alkylidene catalysts also includes dinuclear complexes such as 13, easily obtained from $\mathrm{RuCl}_{2}\left(\mathrm{PPh}_{3}\right)_{3}$ and 1,4-benzene-bis(diazomethane), that provide ready access to particular polymer architectures like ABA block-copolymers by ROMP of cycloolefins ${ }^{26}$ (Scheme 6). 


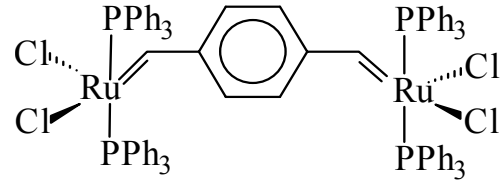

13

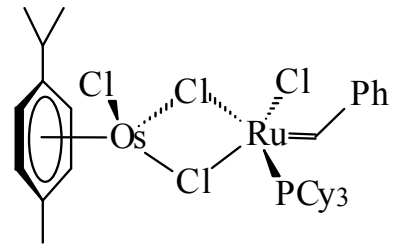

14

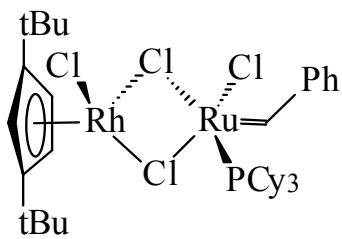

15

Scheme 6. Dinuclear ruthenium alkylidene complexes.

Heterobimetallic ruthenium catalysts are also to be mentioned, e.g. compounds 14 and 15, containing both ruthenium and osmium or rhodium, conveniently resulting from reaction of complex 1 with the corresponding diosmium or dirhodium derivatives. Such heterobimetallic complexes were reported to possess significantly enhanced activity in ROMP of 1,5cyclooctadiene and 2,2-bis(trifluoromethyl)norbornene. ${ }^{27}$

Striking progress in the chemistry of ruthenium carbene complexes was achieved through the synthesis by Herrmann et al. of a novel class, the ruthenium benzylidene complexes 16-19, ${ }^{28,29}$ obtained via derivatization of the phosphane complex 1. To this end, one or both $\mathrm{PCy}_{3}$ ligands in 1 have been replaced by the sterically demanding imidazolin-2-ylidenes, easily accessible and known to be more Lewis-basic than $\mathrm{PCy}_{3}$. In contrast to phosphane, these non-labile ligands possess strong $\sigma$-donor and weak $\pi$-acceptor properties stabilizing both the 16 -electron precatalysts and the highly electron defficient metathesis intermediates. The approach also allowed control of the reactivity by systematic variation of the $\mathrm{R}$ groups in the imidazolin-2ylidene moiety (Scheme 7).

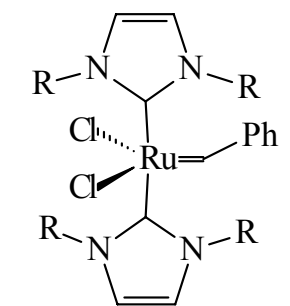

$\mathrm{R}=\mathrm{Cy}, \mathrm{i}-\mathrm{Pr}, \mathrm{CHMePh}$

$\mathrm{R}=\mathrm{CHMe}($ Naphthyl $)$

16

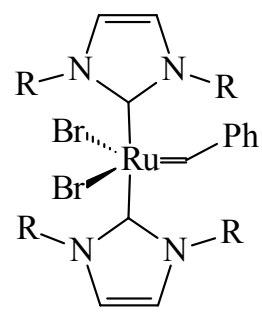

$\mathrm{R}=i-\mathrm{Pr}$

17

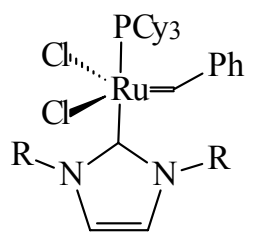

$\mathrm{R}=\mathrm{CHMePh}$

18

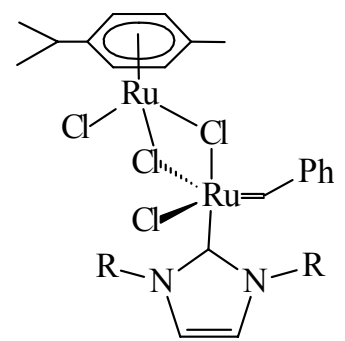

$\mathrm{R}=\mathrm{Cy}$

19

Scheme 7. N-Heterocyclic carbene (NHC) ruthenium complexes.

In spite of significant differences observed in the reactivity of 16-19, these ruthenium benzylidene complexes bearing N-heterocyclic carbenes (NHC) as ancillary ligands were found to promote conversion of a wide panel of dienes or enynes into the corresponding cyclic compounds by ring closing metathesis (RCM) or enyne metathesis (EM). ${ }^{30}$ Applications include synthesis of five-, six-, seven-, eight- and higher-membered ring system compounds, of N- and 
O-heterocyclic compounds (Eq. 7-12), as well as of macrocyclic products such as the commercially important perfume ingredient Exaltolid ${ }^{\circledR}$. Significantly, compatibility between these ruthenium benzylidene complexes and functional groups in different organic compounds seems to practically match that of the complex 1 . An unexpected supplemental advantage of this class of catalysts is their excellent performance in the formation of tri- and even tetra-substituted cycloalkene products by RCM.
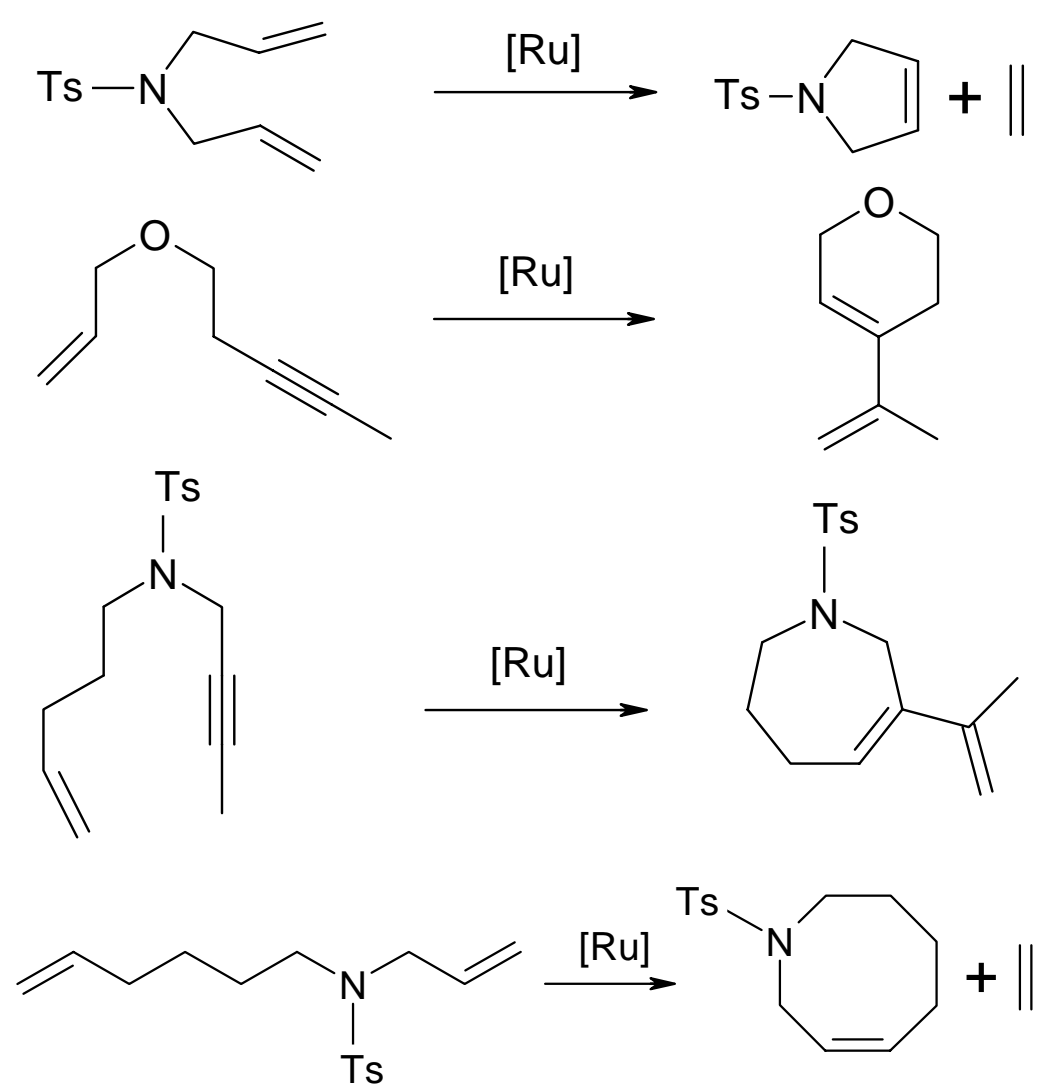

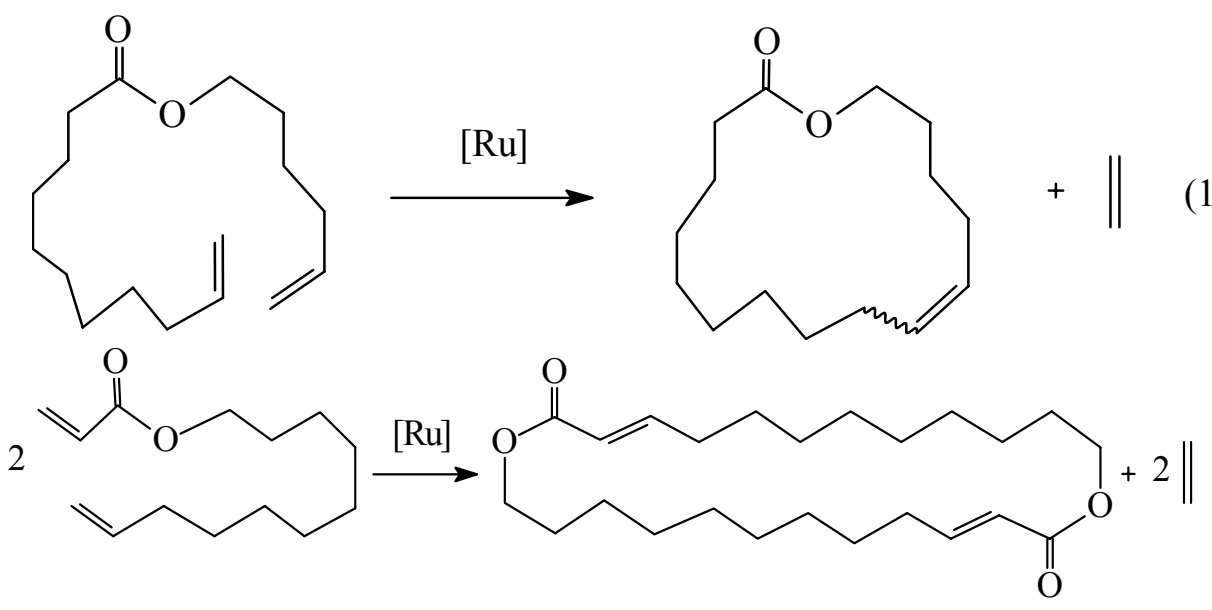

At the same time, on applying a similar procedure for ligand exchange in ruthenium carbene complexes, Grubbs and coworkers ${ }^{31}$ prepared another series of ruthenium catalysts (20-22) 
within the imidazolin-2-ylidene class, using different members of the Arduengo imidazolin-2ylidene ligands ${ }^{32}$ (Scheme 8).<smiles>[R]N1C=CN([R])C1[R](Cl)(Cl)CP</smiles>

$$
\mathrm{R}=2,4,6 \cdot\left(\mathrm{CH}_{3}\right)_{3} \mathrm{C}_{6} \mathrm{H}_{2}
$$<smiles>[R]N1CCN([R])C1[R](Cl)(Cl)CP</smiles>

$\mathrm{R}=2,4,6-\left(\mathrm{CH}_{3}\right)_{3} \mathrm{C}_{6} \mathrm{H}_{2}$<smiles>[R]N1CCN([R])C1[R](Cl)(Cl)CC=C(C)C</smiles>

$\mathrm{R}=2,4,6-\left(\mathrm{CH}_{3}\right)_{3} \mathrm{C}_{6} \mathrm{H}_{2}$

Scheme 8. N-Heterocyclic carbene (NHC) ruthenium complexes of the Grubbs type.

Synthesis occurs readily by a two-step sequence. In the first step, the imidazolin-2-ylidene carbene ligand is conveniently synthesized from the corresponding salt with sodium hydride in liquid ammonia/THF, and used without purification in the subsequent step involving a ligand exchange reaction in the ruthenium complex 1; the latter reaction is rapid at room temperature, in toluene. The final product was isolated as a pinkish-brown microcrystalline solid that could be purified by recrystallization from pentane at $-78^{\circ} \mathrm{C}$. Of the numerous 1,3 -diaryl-imidazolin-2ylidenes tried by Grubbs, only the 2,6-disubstituted aryls (including the 1,3-dimesitylimidazolin-2-ylidene), which are sufficiently bulky to prevent substitution of the second phosphane ligand, gave clean reaction products. Synthesis and characterization of NHC ruthenium alkylidene complexes were reported simultaneously by the Nolan group as well. ${ }^{33}$

Very stable and highly selective for cross-metathesis (CM) and ring-closing metathesis (RCM) proved to be the O-chelated NHC ruthenium isopropoxy-benzylidene complex 23, incorporating a 1,3-dimesitylimidazolidin-2-ylidene ligand, prepared by Hoveyda et al. ${ }^{34}$ (Scheme 9).

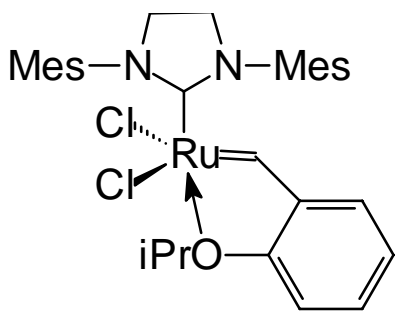

23

Scheme 9. O-Chelated, NHC ruthenium complexes of Hoveyda type. 
Two alternative synthetic pathways for the ruthenium benzylidene complex 23, employing as precursors different ruthenium alkylidene complexes, have been reported by Blechert et al. ${ }^{35}$ (Scheme 10).<smiles>FP(F)(P)(Cl)C(=C1C(c2ccccc2)=Cc2ccccc21)P(P)(P)(Cl)Cl</smiles><smiles>CCOC1N(C)CCN1S(C)(=O)=O</smiles><smiles></smiles>

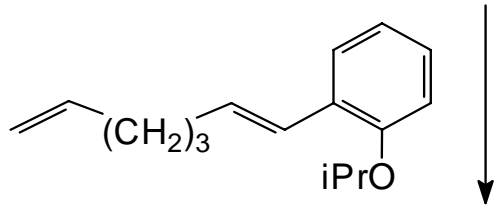

$40 \%$
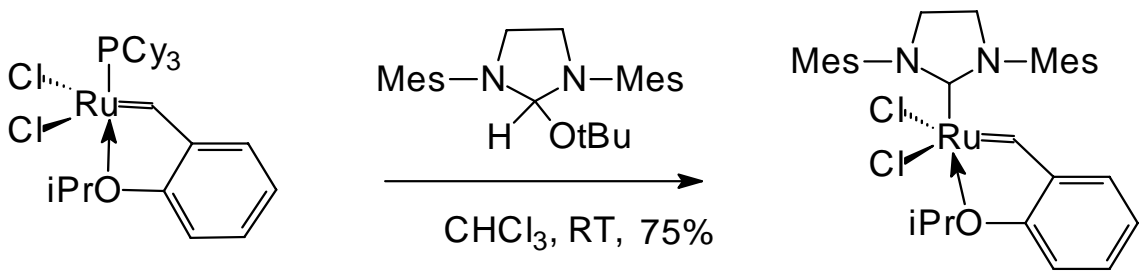

23

Scheme 10. Convenient synthesis of ruthenium complexes of the Hoveyda type.

Of great interest for asymmetric metathesis chemistry is the family of chiral ruthenium alkylidene complexes. In this juncture, the ruthenium benzylidene complexes 24-26, which use backbone stereogenicity to induce atropisomeric chirality in the unsymmetrical $\mathrm{N}$-aryl substituents, have been synthesized and applied in metathesis reactions. ${ }^{36,37}$ Among these complexes, compound $\mathbf{2 6}$ exhibited considerable metathesis activity and a particularly enhanced stereoselectivity. $^{37}$

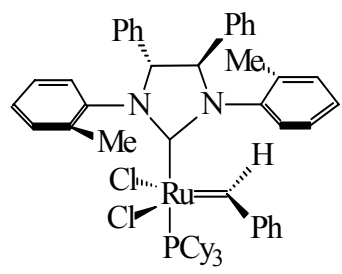

24

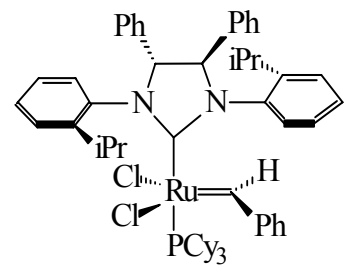

25

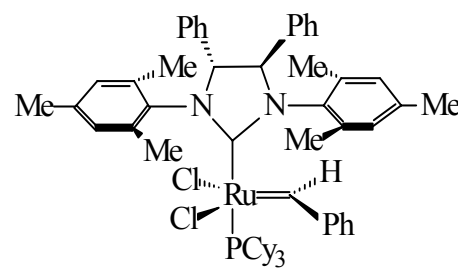

26

Scheme 11. Chiral ruthenium benzylidene complexes.

Other new chiral ruthenium complexes, 27 and 28, bearing different alkylidene moieties, also have been synthesized and used in enantioselective metathesis reactions. ${ }^{38}$ 


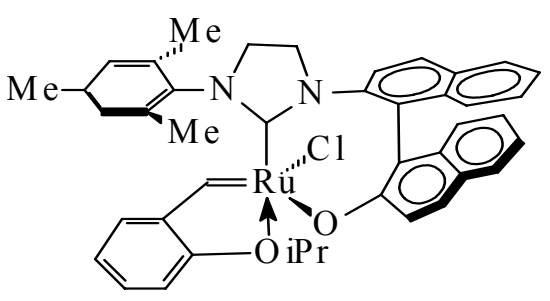

27

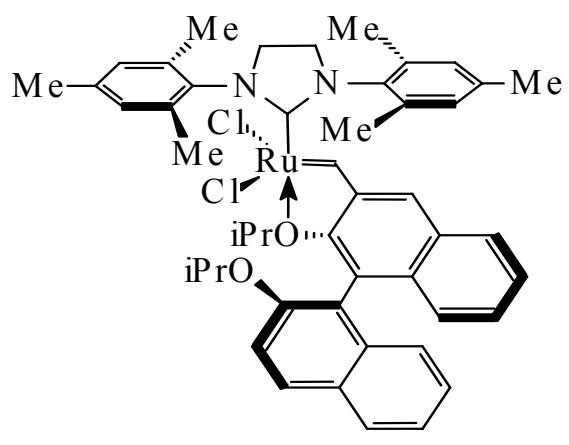

28

Scheme 12. Chiral O-chelated ruthenium benzylidene complexes.

Remarkably, over 98\% enantioselectivity has been reported when applying complex 27 in ring-opening metathesis of a norbornene derivative and a substituted olefin ${ }^{38 a}$ (Scheme 13).

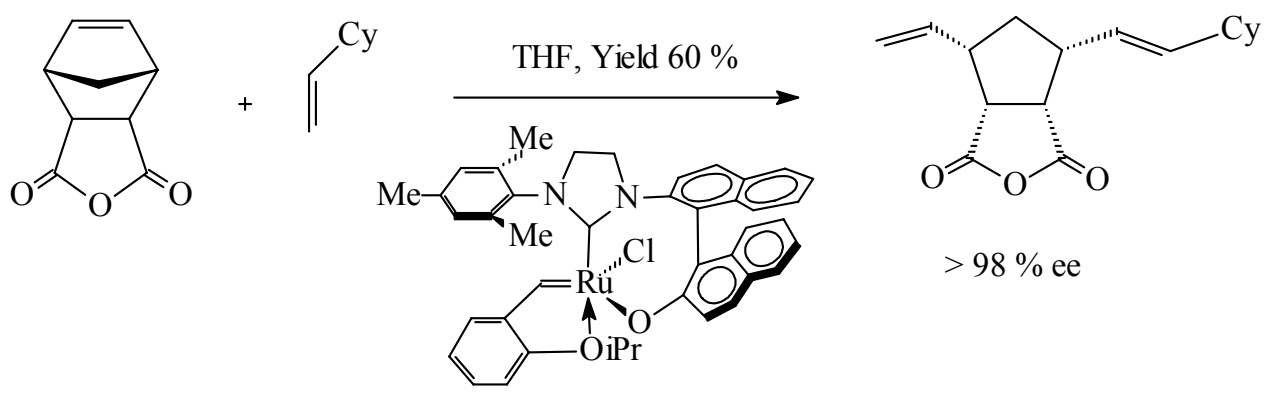

Scheme 13. Enantioselective ring-opening metathesis with chiral ruthenium complexes.

\section{Ruthenium vinylidene complexes}

Ruthenium vinylidene complexes also are having a considerable impact on metathesis related chemistry. ${ }^{39 a, b}$ Originally, the neutral 16 -electron ruthenium vinylidene complexes $30(\mathrm{R}=i$ $\mathrm{Pr}, \mathrm{Cy} ; \mathrm{R}^{\prime}=\mathrm{Ph}, t$-Bu, Fc, $\left.p-\mathrm{MeO}_{2} \mathrm{CC}_{6} \mathrm{H}_{4}, p-\mathrm{MeOC}_{6} \mathrm{H}_{4}\right)$ were prepared by Katayama and Osawa $^{39 c, d}$ from commercially available starting materials, namely terminal alkynes and the arene ruthenium dimer 29.

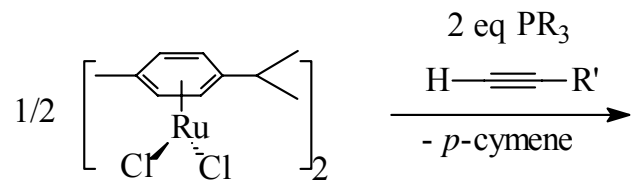

29<smiles>[R]C=C([R17])[R]([R16])([H])Cl</smiles>

30

Scheme 14. Bisphosphane ruthenium vinylidene complexes. 
However, these complexes showed only moderate metathesis activity in RCM of unsubstituted $\alpha, \omega$-dienes and ROMP of higly strained norbornenes. ${ }^{40}$

Other interesting cationic and neutral 18-electron ruthenium vinylidene complexes were obtained by Bruce ${ }^{41 a}$, Osawa ${ }^{41 b}$ (31-33) and van $\operatorname{Koten}^{42}$ (34-36) and were screened for their metathesis activity, but their applicability remains limited to a small range of olefinic substrates.

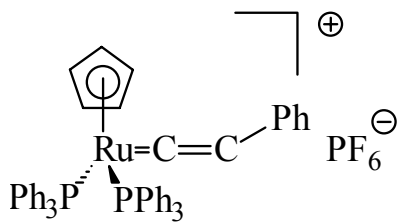

31

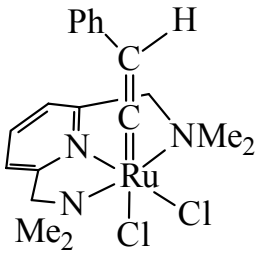

34

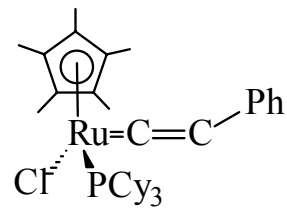

32

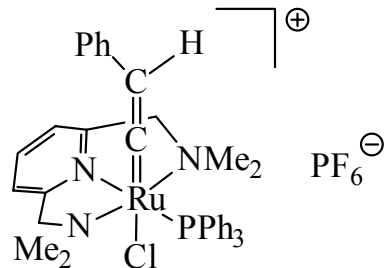

35

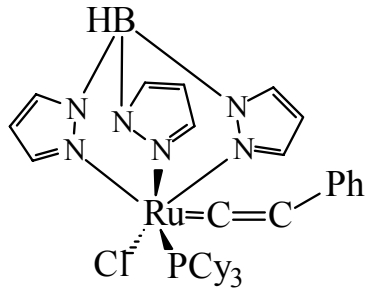

33

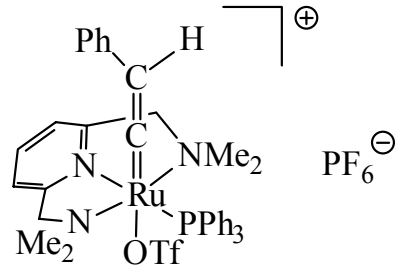

36

Scheme 15. Cationic and neutral ruthenium vinylidene complexes.

A substantial improvement was accomplished by Louie and Grubbs through synthesis of ruthenium vinylidene complexes coordinating an imidazolin-2-ylidene ligand. ${ }^{43}$ Complexes 37 resulted from the bisphosphane ruthenium complex $\mathbf{1}(\mathrm{R}=\mathrm{Cy})$ and free imidazoline carbenes or their salts (Scheme 16).

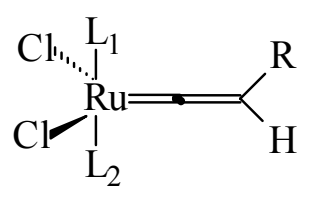

$$
\begin{aligned}
& \mathrm{L}_{1}=\mathrm{L}_{2}=\mathrm{PCy}_{3}, \mathrm{R}=\mathrm{Ph} \\
& \mathrm{L}_{1}=\mathrm{L}_{2}=\mathrm{PCy}, \mathrm{R}=t-\mathrm{Bu} \\
& \mathrm{L}_{1}=\mathrm{L}_{2}=1,3-i-\mathrm{Pr}_{2}-4,5-\mathrm{Me}_{2} \mathrm{Im}, \mathrm{R}=\mathrm{Ph} \\
& \mathrm{L}_{1}=1,3-\mathrm{Mes}_{2} \mathrm{Im}, \mathrm{L}_{2}=\mathrm{PCy}_{3}, \mathrm{R}=t-\mathrm{Bu}
\end{aligned}
$$

37

Scheme 16. Ruthenium complexes bearing various ancillary ligands.

In this class, complexes possessing both the phosphane and imidazolin-2-ylidene ligands, displayed substantial metathesis activity in RCM of diethyl diallylmalonate yielding substituted cycloolefin, but the reaction rate was slower than that with the corresponding bisimidazolin-2ylidene ruthenium vinylidene complex. As detailed mechanistic investigations on the metathesis reaction by Grubbs and coworkers ${ }^{43}$ cogently displayed that increased ligand dissociation (i.e. of 
phosphane) is necessary to accelerate the initiation step and thereby enhance the catalytic activity, a coordinatively unsaturated, phosphane-free ruthenium vinylidene complex $\mathbf{3 8}$ might be formed directly in situ from the ruthenium dimer 29, in the presence of a terminal alkyne and the N-heterocyclic carbene (IMes), as such or as its salts.

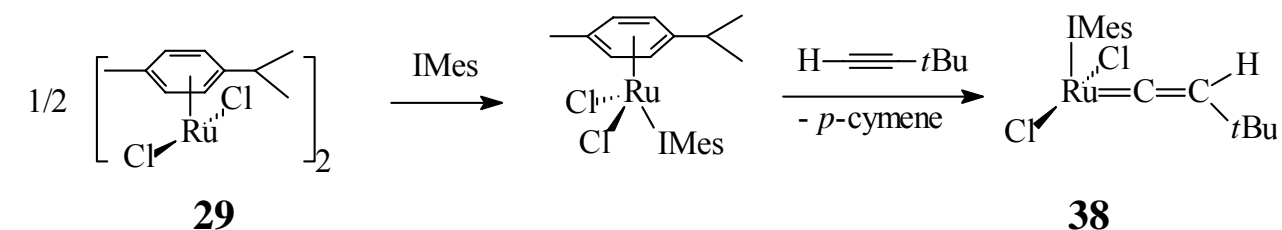

Scheme 17. Synthesis of imidazolin-2-ylidene ruthenium vinylidene complex 38.

Indeed, the catalytic activity of $\mathbf{3 8}$ proved to be even higher than that of the complex $\mathbf{3 5}$, evidencing a higher unsaturation degree in the coordination metal sphere. The pathway for generation of the real catalytically active species, 39, from 38 and the olefin substrate can be seen in Scheme 18.

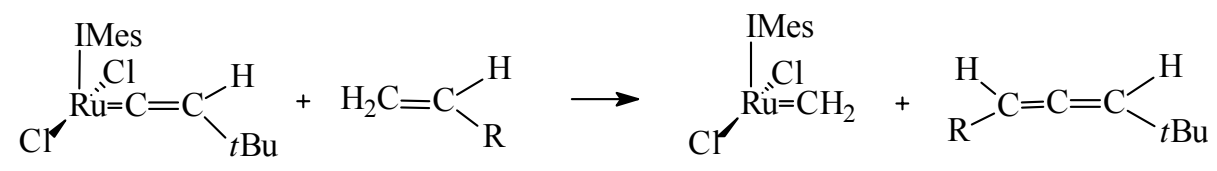

Scheme 18. Generation of the active species from catalyst 38.

\section{Ruthenium indenylidene complexes}

First, 3-phenyl indenylidene complex 40 was prepared from commercial $\left[\mathrm{RuCl}_{2}\left(\mathrm{PPh}_{3}\right)_{4}\right]$ and 3,3diphenylpropyn-3-ol as the carbene source. Then, the $\mathrm{PPh}_{3}$ ligands in complex $\mathbf{4 0}$ were readily substituted by the better donating $\mathrm{PCy}_{3}$ affording the parent indenylidene complex $41 .{ }^{44,45}$

$$
\left[\mathrm{RuCl}_{2}\left(\mathrm{PPh}_{3}\right)_{4}\right] \quad \stackrel{\mathrm{HC} \equiv \mathrm{CCPh}_{2} \mathrm{OH}}{\stackrel{-\mathrm{H}_{2} \mathrm{O}}{-2 \mathrm{PPh}_{3}}}
$$

40
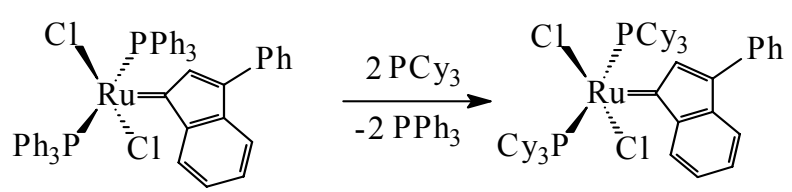

41

Scheme 19. Synthesis of ruthenium indenylidene complexes $\mathbf{4 0}$ and $\mathbf{4 1 .}$

The methodology can also use the trisphosphane complex $\left[\mathrm{RuCl}_{2}\left(\mathrm{PPh}_{3}\right)_{3}\right]$ for synthesis of indenylidene complex $\mathbf{4 0}$. It has been proved unequivocally that the initially formed allenylidene 
complex 42 leads by intramolecular rearrangement to the more stable indenylidene complex 40. ${ }^{46}$

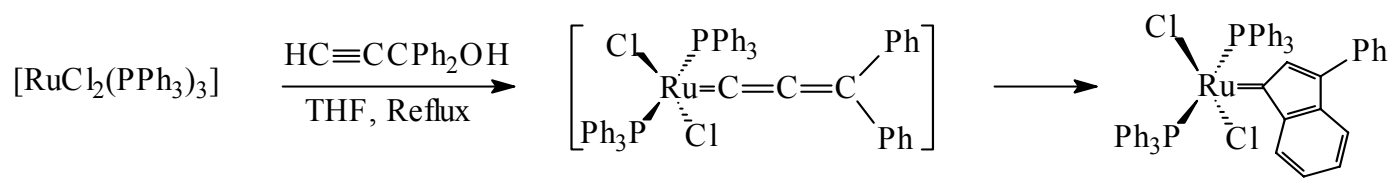

Scheme 20. Reaction pathway for synthesis of ruthenium indenylidene complex $\mathbf{4 0 .}$

These ruthenium indenylidene complexes have higher thermal stability as compared to the related alkylidene complexes $\mathbf{1}$ and $\mathbf{2}$ and also perform well in various ring-closing metathesis reactions.

Substitution of phosphane ligands in complexes $\mathbf{4 0}$ and $\mathbf{4 1}$ by imidazolin-2-ylidene ligands enabled synthesis of new 16-electron ruthenium indenylidene complexes of even higher activity and stability. Thus, addition of 1,3-dimesitylimidazolin-2-ylidene to the 3-phenylindenylidene complexes 40 and 41, in toluene at room temperature, leads to 43 and 44, respectively, in considerable yield ${ }^{47}$ (Scheme 21$)$.

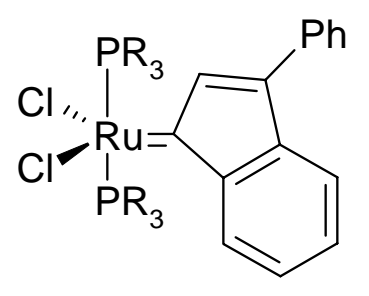

40, $\mathrm{R}=\mathrm{Ph}$
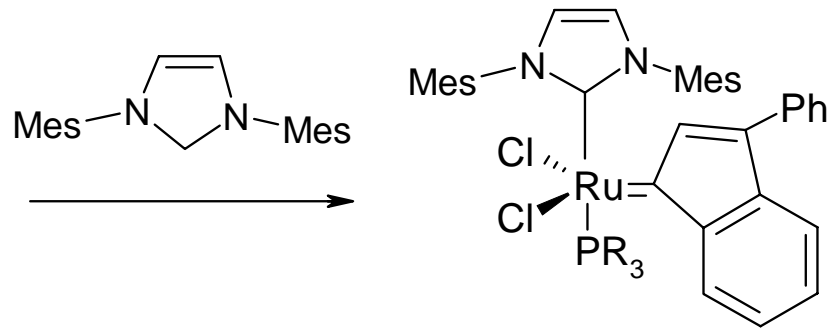

43, $\mathrm{R}=\mathrm{Ph}$

44, $\mathrm{R}=\mathrm{Cy}$

Scheme 21. Synthesis of 1,3-dimesitylimidazolin-2-ylidene ruthenium indenylidene complexes 43 and 44.

Complex 44 can be best prepared in hot hexane because of an easier isolation of the product by simple filtration vs. evaporation of the solvent. By a similar procedure complexes 45 and 46 have been obtained from 40 and 41, respectively, and 1,3-bis(2,6-di-isopropylphenyl)imidazolin2-ylidene (Scheme 22). 
<smiles></smiles>

40, $\mathrm{R}=\mathrm{Ph}$

41, $\mathrm{R}=\mathrm{Cy}$

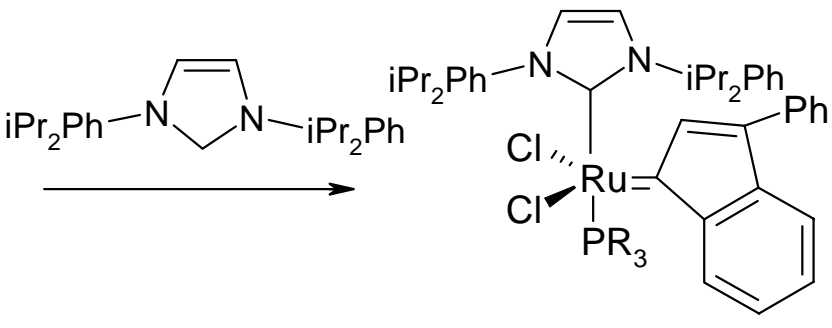

45, $\mathrm{R}=\mathrm{Ph}$

46, $\mathrm{R}=\mathrm{Cy}$

Scheme 22. Synthesis of bis(1,3-diisopropylphenyl)imidazolin-2-ylidene ruthenium indenylidene complexes $\mathbf{4 5}$ and $\mathbf{4 6}$.

Thermal stability studies indicated that compounds $\mathbf{4 4}$ and 46, incorporating a $\mathrm{PCy}_{3}$ ligand, are very stable and do not decompose even after heating to $80^{\circ} \mathrm{C}$ for several days. RCM experiments using diethyl diallylmalonate and diallyl tosylamine as substrates showed a good catalytic activity and selectivity of the ruthenium indenylidene complexes of this precatalyst family (yields of $88 \%$ and 94\% were recorded for 44 and 46, respectively). (Schemes 23 and 24).
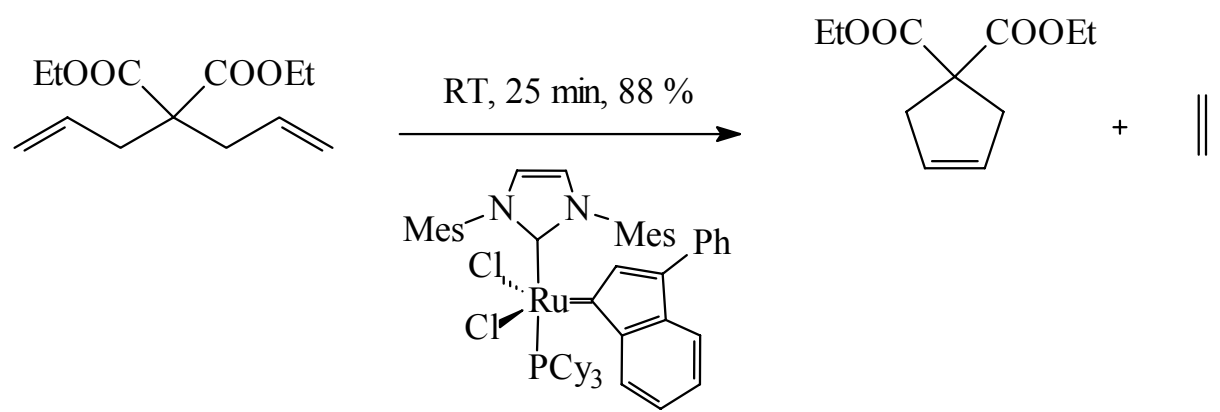

44

Scheme 23. RCM using ruthenium indenylidene catalyst 44 .<smiles>C=CCN([Tl])CC=C</smiles>

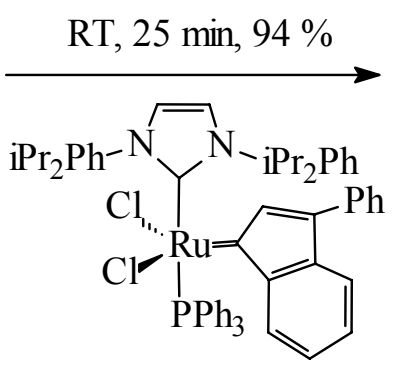<smiles>C=C[C+]1CC=CC1</smiles>

Scheme 24. RCM using ruthenium indenylidene catalyst 46. 
Interesting ruthenium indenylidene complexes containing Schiff-bases as ligands arise from diphosphane ruthenium indenylidene complexes and aromatic salicylaldimines. For instance, complex 47 has been obtained in high yield from 41 (Scheme 25). ${ }^{48}$<smiles>Cc1cc(Br)cc(C)c1/N=C/c1ccccc1O</smiles>

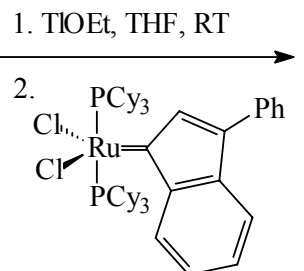

41

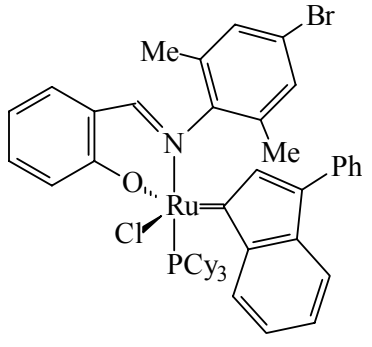

47

Scheme 25. Synthesis of Schiff-base containing ruthenium indenylidene complex 47.

Complex 47 was characterized by means of ${ }^{1} \mathrm{H},{ }^{13} \mathrm{C},{ }^{31} \mathrm{P}-\mathrm{NMR}$ and elemental analysis and successfully applied in enol-ester synthesis (nucleophilic addition of carboxylic acids to terminal alkynes). Importantly, results obtained with catalyst $\mathbf{4 7}$ are comparable with those reported for the best metathesis Ru-catalysts. ${ }^{49}$ Related Schiff-base ruthenium complexes $\mathbf{4 8}$ and $\mathbf{4 9}$ have been prepared analogously and their activity tested in ROMP of cycloolefins and ATRP of vinyl monomers ${ }^{50}$ (Scheme 26).<smiles>[R]c1cc([R])c(/N=C/c2cc([R])ccc2O)c([R])c1</smiles>
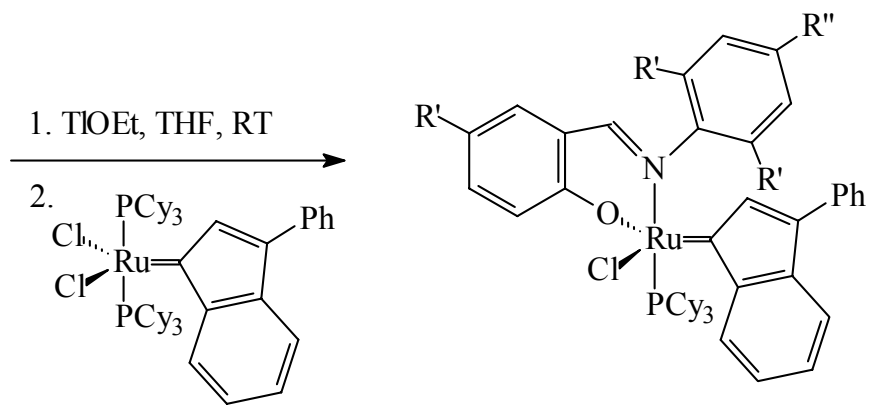

48, $\mathrm{R}^{\prime}=\mathrm{H}, \mathrm{R}$ '” $=i-\operatorname{Pr}, \mathrm{R}^{\prime \prime \prime}=\mathrm{H}$

49, $\mathrm{R}^{\prime}=\mathrm{NO}_{2}, \mathrm{R}$ ' $=\mathrm{Me}, \mathrm{R}{ }^{\prime \prime}$ ' $=\mathrm{Br}$

Scheme 26. Synthesis of Schiff-base containing ruthenium indenylidene complex 48, 49.

In conclusion, we should mention that bidentate Schiff-base ancillary ligands incorporated into this type of complex pronouncedly influence both their activity and stability.

The related arene ruthenium indenylidene complex 50, generated in situ from an allenylidene precursor by treatment with strong acids (e.g., HOTf, $\left.\mathrm{HBF}_{4}\right)$, displayed a high activity in acyclic diene metathesis reaction (ADMET), RCM of diallyl tosylamide, enyne metathesis reaction of allyl propargyl tosylamide and ROMP of cyclopentene and cyclooctene. ${ }^{51}$ For example, in 
ADMET of 1,9-decadiene a polymer yield of $94 \%$ has been obtained after 12 hours in $\mathrm{CD}_{2} \mathrm{Cl}_{2}$ at $0^{\circ} \mathrm{C}$, using as catalyst precursors $\left[\mathrm{RuCl}(p\right.$-cymene $\left.)\left(=\mathrm{C}=\mathrm{C}=\mathrm{CPh}_{2}\right)\left(\mathrm{PCy}_{3}\right)\right]\left[\mathrm{CF}_{3} \mathrm{SO}_{3}\right]$ and $\mathrm{HOSO}_{2} \mathrm{CF}_{3}$ which generate in situ the catalyst 50 (Scheme 27).

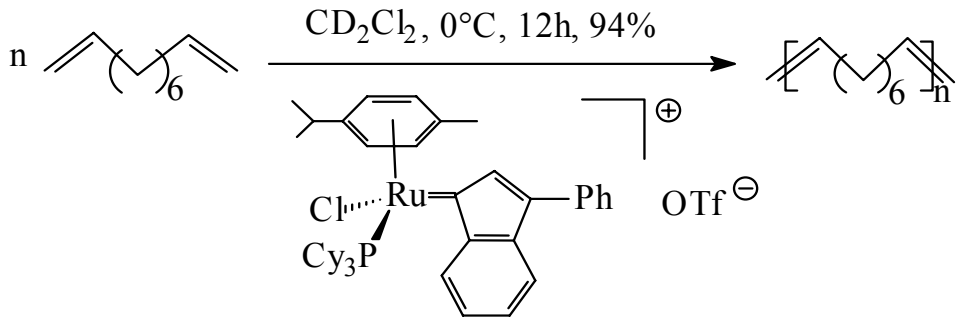

50

Scheme 27. ADMET reaction initiated by catalyst $\mathbf{5 0}$.

Similarly, when using the same catalytic system, 99\% pyrroline N-tosylamide was produced in RCM of diallyl tosylamide, after 10 minutes reaction time (Scheme 28) whereas in enyne metathesis of allylpropargyl tosylamide $75 \%$ of 3-vinylpyrroline N-tosylamide was obtained, under the same conditions. ${ }^{51}$ (Scheme 29)

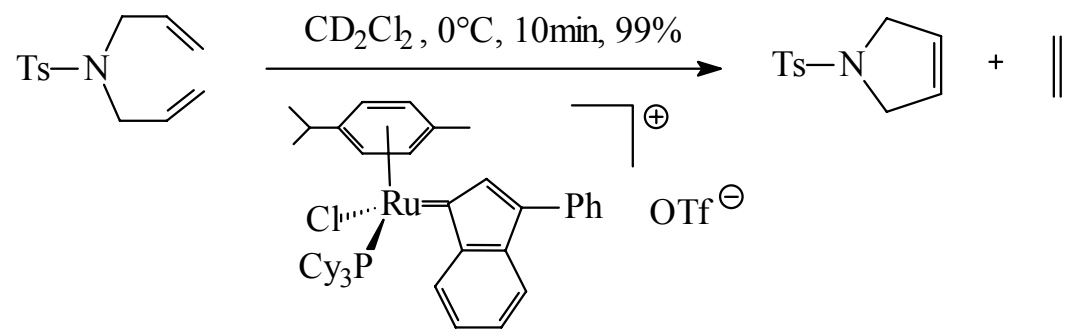

50

Scheme 28. RCM reaction initiated by catalyst 50 .

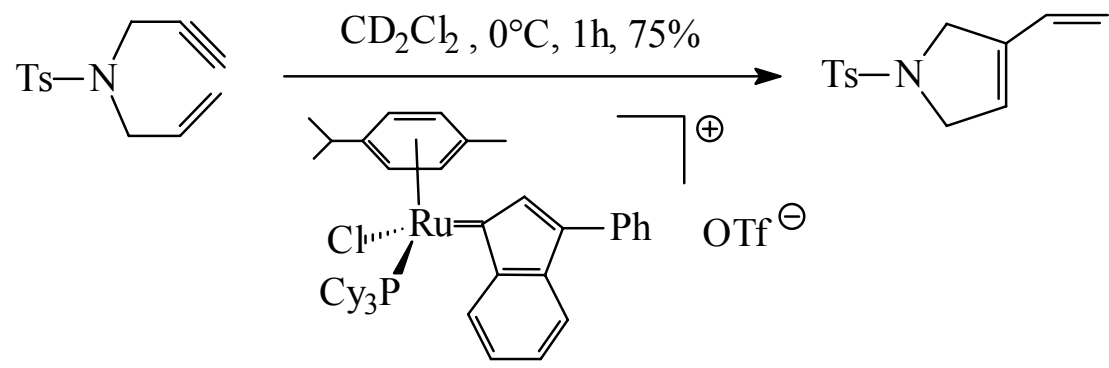

50

Scheme 29. Enyne metathesis reaction initiated by catalyst $\mathbf{5 0 .}$ 
It is important to point out that in ring-opening metathesis polymerization (ROMP) of cyclooctene with the system $\left[\mathrm{RuCl}(\right.$ p-cymene $\left.)\left(=\mathrm{C}=\mathrm{C}=\mathrm{CPh}_{2}\right)\left(\mathrm{PCy}_{3}\right)\right]\left[\mathrm{CF}_{3} \mathrm{SO}_{3}\right] / \mathrm{HOSO}_{2} \mathrm{CF}_{3}$, in chlorobenzene, an unexpectedly high yield of polyoctenamer was obtained after a short reaction time at room temperature (Scheme 30), whereas when starting from a less reactive monomer, cyclopentene, a maximum yield of $67 \%$ could be reached even after 1 hour at $0^{\circ} \mathrm{C} .{ }^{51}$

n

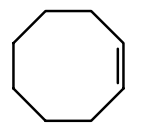

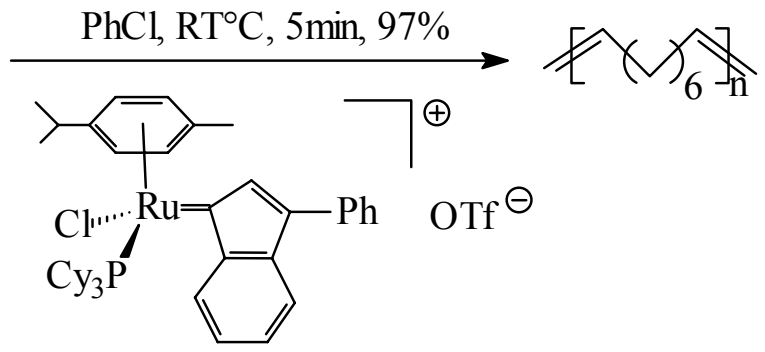

50

Scheme 30. ROMP of cyclooctene initiated by catalyst 50.

\section{Ruthenium allenylidene complexes}

The family of neutral and cationic ruthenium allenylidene complexes is large but up to now only a limited number of its members have been verified as active metathesis catalysts. ${ }^{52}$ Special attention has been paid to three neutral, coordinatively unsaturated 16-electron ruthenium allenylidene complexes, namely the bisphosphane complex 51, the imidazolin-2-ylidene complex 52 and the binuclear complex 53 whose catalytic efficiency for alkene metathesis reactions has been investigated extensively (Scheme 31). ${ }^{53,54}$

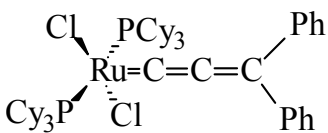

51

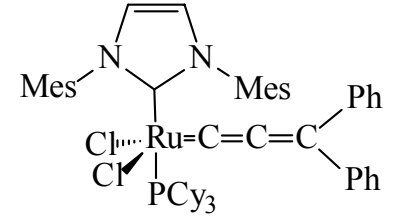

52

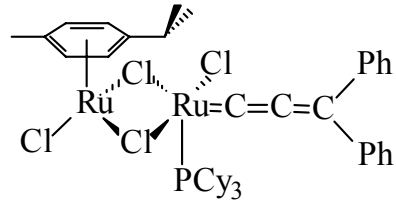

53

Scheme 31. Neutral ruthenium allenylidene complexes.

Bisphosphane complex 51 is the allenylidene analogue of the Grubbs catalyst 1 with $\mathrm{PCy}_{3}$ ligands. Its counterpart having $\mathrm{PPh}_{3}$ groups seems to be rather unstable under normal conditions and to rearrange readily to the indenylidene complex. The more stable but less active, imidazolin-2-ylidene complex 52, an allenylidene analogue of the benzylidene complex 20, stems from complex 51. Binuclear allenylidene complex 53, a highly active metathesis 
ruthenium complex, is related to the binuclear ruthenium benzylidene complex $\left[\mathrm{Ru}_{2} \mathrm{Cl}_{4}(p\right.$ cymene $\left.)(=\mathrm{CHPh})\left(\mathrm{PCy}_{3}\right)\right]$ reported by Grubbs and coworkers. ${ }^{27}$

At variance with the former group of neutral allenylidene complexes, a larger number of cationic, coordinatively saturated 18 -electron ruthenium allenylidene complexes have been reported and applied with excellent results in a variety of metathesis reactions. ${ }^{55}$ Essentially, these allenylidene complexes, e.g., 54-57, contain $\eta^{6}$-arene ligands associated with additional phosphane and chloride ligands, in conjunction with a "non-coordinating" counterion $\mathrm{X}^{-}$ (Scheme 32).

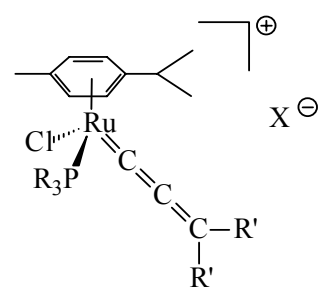

54

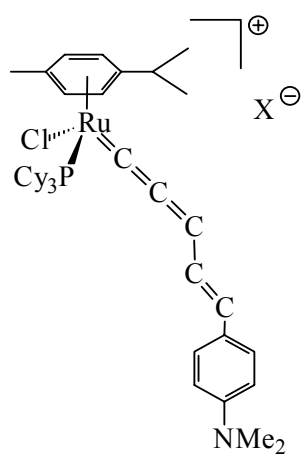

55

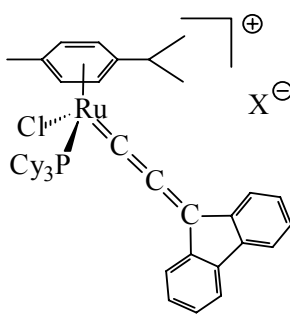

56

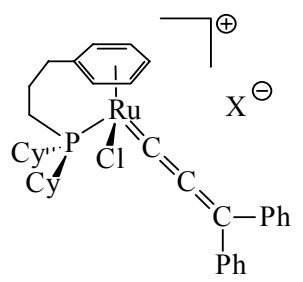

57

Scheme 32. Cationic ruthenium allenylidene complexes.

By varying the phosphine substituents $(\mathrm{R}=\mathrm{Ph}, \mathrm{Cy}, \mathrm{i}-\mathrm{Pr})$, the nature of the counterion $\mathrm{X}^{-}(\mathrm{X}=$ $\mathrm{PF}_{6}, \mathrm{BPh}_{4}, \mathrm{BF}_{4}, \mathrm{OTf}$, etc) and the terminal groups on the allenylidene moiety $\left(\mathrm{R}^{\prime}=\mathrm{Ph}, p\right.$ chlorophenyl, $p$-methoxyphenyl, etc), the number of available complexes of this type has been increased. Their potential as metathesis precatalysts was also thoroughly evaluated.

\section{Miscellaneous ruthenium complexes}

Two very active cationic ruthenium complexes, $\mathbf{5 8}$ and $\mathbf{5 9}$, introduced by Werner and coworkers $^{56}$ and Hofmann and coworkers ${ }^{57}$ should also be mentioned. The former has the structure of a hexacoordinated ruthenium carbyne complex while the latter is a ruthenium vinyl carbene bearing a bidentate phosphane ligand. (Scheme 33)

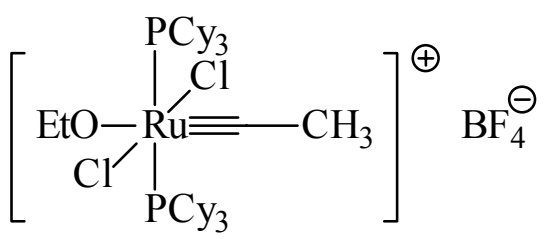

58

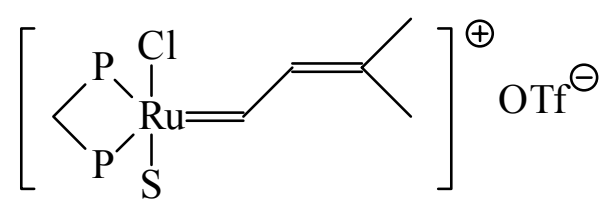

59

Scheme 33. Ruthenium carbyne and vinyl carbene catalysts $\mathbf{5 8}$ and $\mathbf{5 9}$. 
Catalysts 58 and 59 are easily accessible and display a quite high activity in ring-closing metathesis reactions.

\section{Immobilized ruthenium complexes}

Immobilization of ruthenium alkylidene complexes, due to innovative research by Nguyen and Grubbs, ${ }^{58}$ using cross-linked polystyrene-divinylbenzene as the solid support, and by Verdonck et al., ${ }^{59}$ using a dendrimeric carbosilane core, is a further development in metathesis catalysis. The latter catalysts were manufactured by attaching ruthenium alkylidenes to the boundary of the zero-th generation (G0) and first generation (G1) of the carbosilane dendrimers (Scheme 34).

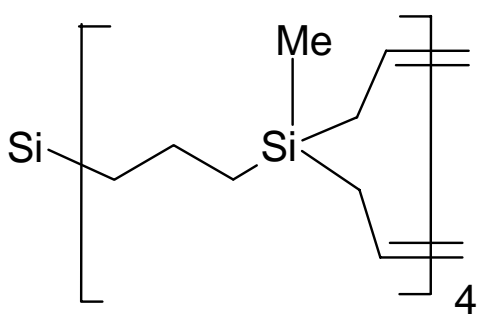

G1

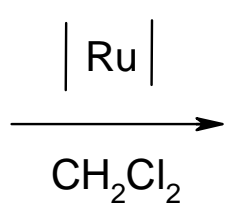

\section{4}

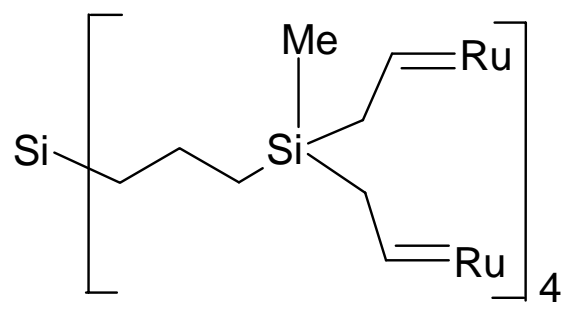

60

Scheme 34. Immobilized ruthenium complexes using a dendrimeric carbosilane core.

The catalytic activity of the dendrimeric ruthenium catalyst $\mathbf{6 0}$ has been tested in ROMP of norbornene. By means of such complexes, multi-arm star polymers could be produced in a controlled manner.

Barrett and coworkers ${ }^{60,61}$ heterogenized bisphosphane ruthenium complex $\mathbf{1}$ on polystyrene and evidenced that it was possible to use the supported catalyst in RCM of ethyl diallylmalonate and ROMP of norbornene. Highly efficient immobilized catalysts have been obtained from NHC ruthenium alkylidene complexes deposited on various solid supports. For instance, the saturated imidazolin-2-ylidene ruthenium complex 21 has been directly microencapsulated in polystyrene by Barrett ${ }^{62}$ and Gibson ${ }^{63}$ or anchored on a polystyrene support by Blechert and coworkers. ${ }^{64}$

More recently, research efforts in the Verpoort group have been directed to the design, synthesis and implementation of heterogeneous Schiff-base ruthenium catalysts in applications in ring-closing metathesis (RCM), ring-opening metathesis polymerization (ROMP), Kharasch addition, atom transfer radical polymerization (ATRP), as well as in vinylation reactions. ${ }^{65-72}$ In order to enhance the commercial potential of the above chemical processes, these researchers have achieved synthesis of two multifunctional Schiff-base ruthenium carbene complexes deposited on MCM-41 (61 and 62) thus providing recyclable and efficient solid catalysts ${ }^{70,71}$ (Scheme 35). 


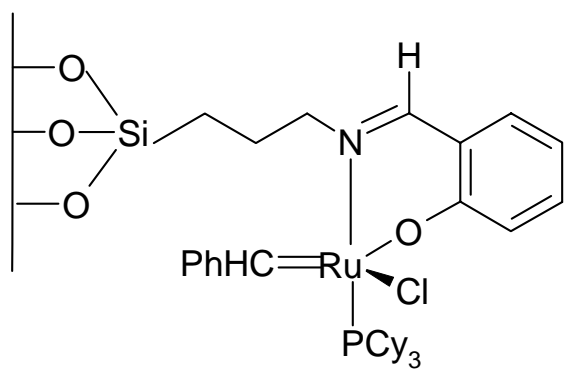

61

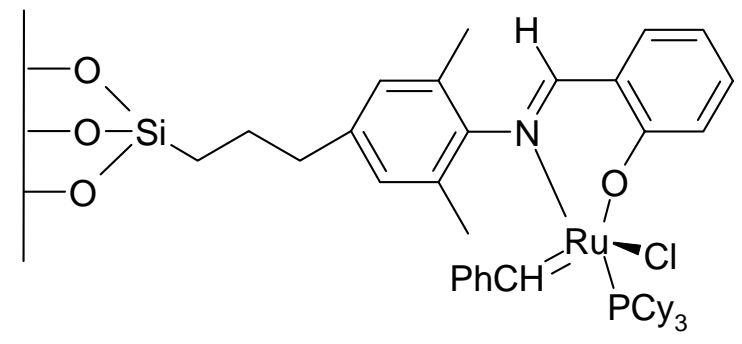

62

Scheme 35. Immobilized Schiff-base ruthenium benzylidene catalysts 61 and 62.

The methodology followed for preparation of the chemically tethered catalyst onto MCM-41 consisted of immobilizing a previously synthesized precursor containing an anchorable functionality. In the case of $\mathbf{6 1}$ and $\mathbf{6 2}$, the mesoporous silica surfaces were treated with the respective tris(alkoxy)silyl-functionalized complex, a commonly applied procedure to tether organometallic compounds onto solid supports. For the solid supported catalysts 61 and 62 two different routes have been employed. ${ }^{71}$ Structural examination by Raman spectroscopy, X-ray diffraction, X-ray fluorescence, solid-state $\mathrm{NMR}$ and $\mathrm{N}_{2}$-adsorption analysis showed that in all cases the anchoring of the homogeneous catalyst via a spacer onto the MCM-41 surface took place through two or three covalent bonds. ${ }^{69}$

A similar approach has been exploited to synthesize and characterize another new heterogeneous ruthenium catalyst, 63, that exhibited good stability, reusability and leaching characteristics in both ring-closing metathesis of heteroatom containing dienes giving heterocycles and atom transfer radical addition of halogenated alkanes to olefins yielding polyhalogenated alkanes ${ }^{71,72}$ (Scheme 36 ).

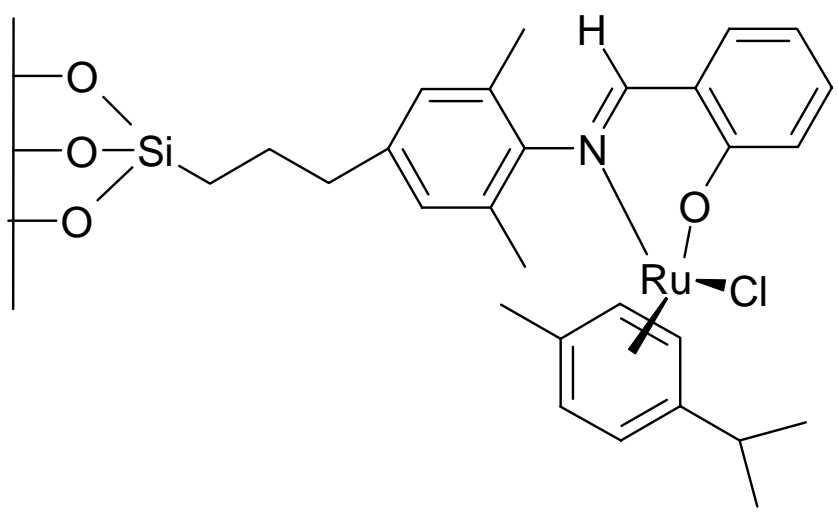

63

Scheme 36. Immobilized Schiff-base ruthenium arene catalyst 63. 


\section{Conclusions}

During the last decade, the number of ruthenium metathesis catalysts has rapidly expanded owing to their accessibility, remarkable activity and selectivity, encountered generally in conjuction with good tolerance towards polar organic functionalities, air and moisture. A significant advancement in this area was achieved through the introduction of imidazolin-2ylidene ligands into conventional ruthenium alkylidene complexes. Many of these catalytic systems can be prepared conveniently starting from the classical Grubbs' ruthenium benzylidene catalyst. New trends in process development are currently being opened through design and synthesis of immobilized ruthenium catalysts. Ruthenium complexes enjoy an excellent application profile in metathesis reactions, and particularly in ring-closing metathesis (RCM), cross-metathesis $(\mathrm{CM})$, enyne metathesis (EM), ring-opening metathesis (ROM) and ringopening metathesis polymerization (ROMP).

\section{Acknowledgements}

We gratefully acknowledge support from the Romanian Academy for the research carried out in connection with this paper. We also thank reviewers for useful comments and suggestions.

\section{References}

1. For recent reviews, see: (a) Dragutan, V.; Dragutan, I.; Balaban, A. T. Platinum Metals Rev. 2000, 44, 58. (b) Fürstner, A. Angew. Chem. Int. Ed. 2000, 39, 3012. (c) Roy, R.; Das, S. K. Chem. Commun. 2000, 519. (d) Dragutan, V.; Dragutan, I.; Balaban, A. T. Platinum Metals Rev. 2001, 45, p 155. (e) Trnka, T. M.; Grubbs, R. H. Acc. Chem. Res. 2001, 34, 18. See also: (f) Dragutan, V.; Dragutan, I.; Verpoort, F. Platinum Metals Rev. 2005, 49, 3.

2. For selected references, see: (a) Grubbs, R.H., Ed., Handbook of Metathesis, Vol. I-III, Wiley-VCH: Weinheim, 2003. (b) Buchmeiser, M. Chem. Rev. 2000, 100, 1565; (c) Randall, M. L.; Snapper, M. L. The Strem Chemiker 1998, 17, 1. (d) Ivin, K.J. J. Mol. Catal. A-Chem. 1998, 133, 1. (e) Imamoglu, Y.; Bencze, L., Eds., Novel Metathesis Chemistry: Well-defined Initiator Systems for Speciality Chemical Synthesis, Tailored Polymers and Advanced Material Applications, Kluwer Academic Publishers: Dordrecht, The Netherlands, 2003.

3. For comprehensive reviews, see: (a) Schrock, R. R.; Hoveyda, A. H. Angew. Chem. Int. Ed. 2003, 42, 4592. (b) Feldman, J; Schrock, R. R. Prog. Inorg. Chem. 1991, 39, 1. For selected references, see: (c) Schaverien, C. J.; Schrock, R. R.; Dewan, J. C. J. Am. Chem. Soc. 1986, 108, 2771. (d) Schrock, R.R.; DePue, D.T.; Feldman, J.; Schaverien, C. J.; Dewan, J. C.; Liu, A. H. J. Am. Chem. Soc. 1987, 109, 1423. 
4. For selected references, see: (a) O’Dell, R.; McConville, D. H.; Hofmeister, G. H.; Schrock, R.R. J. Am. Chem. Soc. 1994, 116, 3414. (b) McConville, D. H.; Wolf, J. R.; Schrock, R. R. J. Am. Chem. Soc. 1993, 115, 4413.

5. (a) Deiters, A.; Martin, S. F. Chem. Rev. 2004, 104, 199. (b) Kotha, S.; Manivannan, E. ARKIVOC 2003, (iii), 67. (c) Fürstner, A. Angew. Chem. 2000, 112, 3140. (d) Furstner, A. Top. Organomet. Chem. 1998, 1, 37. (e) Furstner, A. Alkene Metathesis in Organic Synthesis, Springer, Berlin, 1998. (f) Mohapatra, D. M.; Durugkar, K. A. ARKIVOC 2004, (i), 146. (g) Mohapatra, D. M.; Yellol, G. S. ARKIVOC 2003, (ix), 21. (h) Rajesh, S.; Srivastava, J.; Iqbal, J. ARKIVOC 2001, (viii), 20. (i) Zuercher, W. J.; Hashimoto, M.; Grubbs, R. H. J. Am. Chem. Soc. 1996, 118, 6634.

6. (a) Chatterjee, A. K.; Choi, T.-L.; Sanders, D. P.; Grubbs, R. H. J. Am. Chem. Soc. 2003, 125, 11360. (b) Zaja, M.; Connon, S. J.; Dunne, A. M.; Rivard, M.; Buschmann, N.; Jiricek, J.; Blechert, S. Tetrahedron 2003, 59, 6545. (c) Arjona, O.; Csaky, A. G.; Carmen Murcia, M.; Plumet, J. ARKIVOC 2002, (v), 171. (d) Connon, S. J.; Blechert, S. Angew. Chem. Int. Ed. 2003, 42, 1900.

7. (a) Diver, S. T.; Giessert, A. J. Chem. Rev. 2004, 104, 1317. (b) Poulsen, C. S.; Madsen, R. Synthesis 2003, 1.

8. (a) Tindall, D; Wagener, K. B. Macromolecules 2004, 37, 3328. (b) Couchay, F. C.; Sworen, J. C.; Wagener, K. B. Macromolecules 2003, 36, 8231.

9. (a) Dragutan, V.; Streck, R. Catalytic Polymerization of Cycloolefins, Elsevier, Amsterdam, The Netherlands, 2000. (b) Ivin, K. J.; Mol, J. C. Olefin Metathesis and Metathesis Polymerization, Academic Press, London, 1997.

10. Khosravi, E.; Szymanska-Buzar, T. Eds; ROMP and Related Chemistry: State of the Art and Visions for the New Century, Kluwer Academic Publishers: Dordrecht, The Netherlands, 2002.

11. (a) Schwab, P.; Grubbs, R. H.; Ziller, J. W. J. Am. Chem. Soc. 1996, 118, 100. (b) Novak, B. M.; Grubbs, R. H. J. Am. Chem. Soc. 1988, 110, 7542.

12. (a) Nguyen, S. T.; Johnson, L. K.; Grubbs, R. H.; Ziller, J. W. J. Am. Chem. Soc. 1992, 114, 3974. (b) Nguyen, T.; Grubbs, R. H.; Ziller J. W. J. Am. Chem. Soc. 1993, 115, 9858.

13. (a) Fu, G. C.; Grubbs, R. H. J. Am. Chem. Soc. 1992, 114, 5426. (b) Fu, G.C.; Grubbs, R. H. J. Am. Chem. Soc. 1992, 114, 7324.

14. Fu, G. C.; Nguyen, S. T.; Grubbs, R. H. J. Am. Chem. Soc. 1993, 115, 9856.

15. Grubbs, R. H.; Chang, S. Tetrahedron 1998, 54, pp 4413.

16. Schwab, P. E.; France, M. B.; Ziller, J. W.; Grubbs, R. H. Angew. Chem. Int. Ed. 1995, 34, 2039.

17. (a) Dragutan, V.; Dragutan, I.; Balaban, A. T. Platinum Metals Rev. 2000, 44, 112. (b) Dragutan, V.; Dragutan, I.; Balaban, A. T. Platinum Metals Rev. 2000, 44, 168.

18. (a) Van der Schaaf, P. A.; Hafner, A.; Mühlebach, A. U.S. Patent 1996, 5,912,376 (to Ciba AG). (b) Van der Schaaf, P. A.; Hafner, A.; Mühlebach, A.; Kimer, H. J.; Kolly, R.; Rime, 
F. $13^{\text {th }}$ Intl. Symp. Olefin Metathesis and Related Chemistry, Kerkrade: The Netherlands, 1115 July, 1999; Abstracts, 11.

19. Mühlebach, A.; Van der Schaaf, P. A.; Hafner, A.; Rime, F.; Kimer, H. J. In ROMP and Related Chemistry: State of the Art and Visions for the New Century E. Khosravi, T. Szymanska-Buzar, Eds, Kluwer Academic Publishers: Dordrecht, The Netherlands, 2002, pp 23-44.

20. Abele, A.; Wursche, R.; Rieger, B. $13^{\text {th }}$ Intl. Symp. Olefin Metathesis and Related Chemistry, Kerkrade: The Netherlands, 11-15 July 1999; Abstracts, 40.

21. (a) Nieczypor, P.; Van Leeuwen, P. W. N. M.; Mol, J. C.; Lutz, M.; Spek, A. J. Organomet. Chem. 2001, 625, 58. (b) Buchowicz, W.; Nieczypor, P.; Mol, J.C. $13^{\text {th }}$ Intl. Symp. Olefin Metathesis and Related Chemistry, Kerkrade: The Netherlands, 11-15 July 1999; Abstracts, 45.

22. Sanford, M. S.; Henling, L. M.; Grubbs, R. H. Organometallics 1998, 17, 5384.

23. (a) Trnka, T. M.; Dias, E. L.; Day, M. W.; Grubbs, R. H. ARKIVOC 2002, (xiii), 28. (b) Love, J. A.; Sanford, M. S.; Day, M. W.; Grubbs, R. H. J. Am. Chem. Soc. 2003, 125, 10103. (c) Choi, T.-L.; Grubbs, R. H. Angew. Chem. Int. Ed. 2003,42, 1743.

24. (a) De Clercq, B.; Verpoort, F. Adv. Synth. Catal. 2002, 344, 639. (b) De Clercq, B.; Verpoort, F. J. Mol. Catal. A-Chem. 2002, 180, 67.

25. Opstal, T.; Verpoort, F. Angew. Chem. Int. Ed. 2003, 42, 2876.

26. Weck, M.; Schwab, P.; Grubbs, R. H. Macromolecules 1996, 29, 1789.

27. Dias, E. L.; Grubbs, R. H. Organometallics 1998, 17, 2758.

28. (a) Weskamp, T.; Schattenmann, W.; Spiegler, M.; Herrmann, W. A. Angew. Chem. 1998, 110, 2631; (b) Weskamp, T.; Schattenmann, W.; Spiegler, M.; Herrmann, W. A. Angew. Chem. Int. Ed. 1998, 37, 2490.

29. (a) Weskamp, T.; Kohl, F. J.; Hieringer, W.; Gleich, D.; Herrmann, W. A. Angew. Chem. 1999, 111, 2573. (b). Weskamp, T.; Kohl, F.J.; Hieringer, W.; Gleich, D.; Herrmann, W. A. Angew. Chem. Int. Ed. 1999, 38, 2416.

30. (a) Ackermann, L.; Fürstner, A.; Weskamp, T.; Kohl, F. J.; Herrmann, W. A. Tetrahedron Lett. 1999, 40, 4787. (b) Fürstner, A.; Ackermann, L.; Gabor, B.; Goddard, R.; Lehmann, C. W.; Mynott, R.; Stelzer, F.; Thiel, O. R. Chem. Eur. J. 2001, 7, 3236.

31. (a) Scholl, M.; Trnka, T. M.; Morgan, J. P.; Grubbs, R. H. Tetreahedron Lett. 1999, 40, 2247. (b) Scholl, M.; Ding, S.; Lee, C. W.; Grubbs, R. H. Org. Lett. 1999, 1, 953. (c) Bielawski, C. W.; Sherman, O. A.; Grubbs, R. H. Polymer 2001, 42, 4939.

32. (a) Arduengo, A. J.; Harlow, R. L.; Kline, M. J. Am. Chem. Soc. 1991, 113, 361. (b) Arduengo, A. J.; Dias, H. V. R.; Harlow, R. L.; Kline, M. J. Am. Chem. Soc. 1992, 114, 5530. (c) Arduengo, A. J.; Dias, H. V. R.; Kline, M. J. Am. Chem. Soc. 1992, 114, 9724.

33. (a) Huang, J.; Schanz, H. J.; Stevens, E. D.; Nolan, S. P. Organometallics 1999, 18, 5375.

(b) Huang, J.; Stevens, E. D.; Nolan, S. P.; Petersen, J. L. J. Am. Chem. Soc. 1999, 121, 2674. 
34. Garber, S. B.; Kingsbury, J. S.; Gray, B. L.; Hoveyda, A. H. J. Am. Chem. Soc. 2000, 122, 8168.

35. Rand1, S.; Gessler, S.; Wakamatsu, H.; Blechert, S. Synlett. 2001, 3, 430.

36. Scholl, M.; Ding, S.; Lee, C. W.; Grubbs, R. H. Org. Lett. 1999, 1, 953.

37. Seiders, T. J.; Ward, D. W.; Grubbs, R. H. Org. Lett. 2001, 3, 3225.

38. (a) Van Veldhuizen, J. J.; Garber, S. B.; Kingsbury, J. S.; Hoveyda, A. H. J. Am. Chem. Soc. 2002, 124, 4954. (b) Wakamatsu, H.; Blechert, S. Angew. Chem. Int. Ed. 2002, 41, 794.

39. (a) Katayama, H.; Ozawa, F. Coord. Chem. Rev. 2004, 248, 1703. See also: (b) Dragutan, V.; Dragutan, I. Platinum Metals Rev. 2004, 48, 48. (c) Katayama, H.; Ozawa, F. Organometallics 1998, 17, 5190. (d) Katayama, H.; Ozawa, F. Chem. Lett. 1998, 67.

40. (a) Bruneau, C.; Dixneuf, P. H. Acc. Chem. Res. 1999, 32, 311. See also: (b) Wakatsuki, Y.; Yamazaki, H.; Kumegawa, N.; Satoh, T.; Satoh, J. Y. J. Am. Chem. Soc. 1991, 113, 9604. (c) Grünwald, C.; Gevert, O.; Wolf, J.; Gonzales-Herrero, P.; Werner, H. Organometallics 1996, 15, 1960. (d) Wolf, J.; Stüer, W.; Grünwald, C.; Gevert, O.; Laubender, M.; Werner, H. Eur. J. Inorg. Chem. 1998, 1827. (e) Jung, S.; Ilg, K.; Brandt, C. D.; Wolf, H.; Werner, H. Eur. J. Inorg. Chem. 2004, 469. (f) Olivan, M.; Eisenstein, O.; Caulton, K. G. Organometallics 1997, 16, 2227.

41. (a) Bruce, M. I.; Hameister, C.; Swincer, A. G.; Wallis, R. C. Inorg. Synth. 1982, 21, 78. (b) Katayama, H.; Yoshida, T.; Osawa, F. J. Organomet. Chem. 1998, 52, 203. See also, (c) Slugovc, C.; Schmid, R.; Kirchner, K. Coord. Chem. Rev. 1999, 186, 109.

42. Del Rio, R.; Van Koten, G. Tetrahedron Lett. 1999, 40, 1401.

43. Louie, J.; Grubbs, R. H. Angew. Chem. Int. Ed. 2001, 40, 247.

44. Fürstner, A.; Hill, A. F.; Liebl, M.; Wilton-Ely, J. D. E. T. J. Chem. Soc. Chem. Commun. 1998, 601.

45. Schanz, H. J.; Jafarpour, L.; Stevens, E. D.; Nolan, S. P. Organometallics 1999, 18, 5187.

46. Fürstner, A.; Thiel, O. R.; Ackermann, L.; Schanz, H. J.; Nolan, S. P. J. Org. Chem. 2000, 65, 2204.

47. Jafarpour, L.; Schanz, H. J.; Stevens, E. D.; Nolan, S. P. Organometallics 1999, 18, 5416.

48. Opstal, T.; Verpoort, F. Synlett 2002, 935.

49. Fürstner, A.; Grabowski, J.; Lehmann, C. W. J. Org. Chem. 1999, 64, 8275.

50. Opstal, T.; Verpoort, F. Angew. Chem. Int. Ed. 2003, 42, 2876.

51. Castarlenas, R.; Dixneuf, P. H. Angew. Chem. Int. Ed. 2003, 42, 4524.

52. (a) Fürstner, A.; Picquet, M.; Bruneau, C.; Dixneuf, P. H. Chem. Commun. 1998, 1315. (b) Fürstner, A.; Liebl, M.; Lehmann, C. W.; Picquet, M.; Kunz, R.; Bruneau, C.; Touchard, D.; Dixneuf, P. H. Chem. Eur. J. 2000, 6, 1847. See also: (c) Rigaut, S.; Touchard, D.; Dixneuf, P.H. Coord. Chem. Rev. 2004, 248, 1585. (d) Winter, R. F.; Zalis, S. Coord. Chem. Rev. 2004, 248, 1565.

53. Picquet, M.; Touchard, D.; Bruneau, C.; Dixneuf, P. H. New J. Chem. 1999, 23, 141.

54. Picquet, M.; Bruneau, C.; Dixneuf, P. H. Chem. Commun. 1998, 2249. 
55. Castarlenas, R.; Semeril, D.; Noels, A. F.; Demonceau, A.; Dixneuf, P. H. J. Organomet. Chem. 2002, 663, 235.

56. (a) Wolf, J.; Stüer, W.; Grünwald, C.; Werner, H.; Schwab, P.; Schulz, M. Angew. Chem. Int. Ed. 1998, 37, 1124. (b) Werner, H.; Jung, S.; Gonzalez-Herrero, P.; Ilg, K.; Wolf, J. Eur. J. Inorg. Chem. 2001, 1957. (c) Jung, S.; Ilg, K.; Wolf, J.; Werner, H. Organometallics 2001, 20, 2121.

57. (a) Hansen, S. M.; Rominger, F.; Metz, M.; Hofmann, P. Chem. Eur. J. 1999, 5, 557. (b) Hansen, S. M.; Volland, M. A. O.; Rominger, F.; Eisentrager, F.; Hofmann, P. Angew. Chem. Int. Ed. 1999, 38, 1273.

58. Nguyen, S. T.; Grubbs, R. H. J Organomet Chem. 1995, 497, 195.

59. Beerens, H.; Verpoort, F.; Verdonck, L. J. Mol. Catal. A-Chem. 2000, 151, 279.

60. Barrett, A. G. M.; Cramp, S. M.; Roberts, R. S. Org. Lett. 1999, 1, 1083.

61. Ahmed, M.; Barrett, A. G. M.; Braddock, D. C.; Cramp, S. M.; Procopiou, A. Tetrahedron Lett. 1999, 40, 8657.

62. Ahmed, M.; Arnauld, T.; Barrett, A. G. M.; Braddock, D. C.; Procopiou, A. Synlett 2000, 9, 1007.

63. Gibson, S. E.; Swamy, V. M. Adv. Synth. Catal. 2002, 344, 619.

64. Randl, S.; Buschmann, N.; Connon, S. J.; Blechert, S. Synlett 2001, 10, 1547.

65. Opstal, T.; Melis, K.; Verpoort, F. In ROMP and Related Chemistry State of the Art and Visions for the New Century Khosravi, E.; Szymanska-Buzar, T. Eds; NATO-ASI, Polanica Zdroj: Poland, 3-15 September, 2000.

66. Opstal, T.; Melis, K.; Verpoort, F. Catal. Lett. 2001, 74, 155.

67. De Clercq, B.; Opstal, T.; Melis, K.; Verpoort, F. In ROMP and Related Chemistry State of the Art and Visions for the New Century Khosravi, E.; Szymanska-Buzar, T. Eds; NATOASI, Polanica Zdroj: Poland, 3-15 September, 2000.

68. Melis, K.; De Vos, D.; Jacobs, P.; and Verpoort, F. J. Mol. Catal. A-Chem. 2001, 169, 47.

69. De Clerq, B.; Smellinckx, T.; Hughelier, C.; Maes, N.; Verpoort, F. Appl. Spectr. 2001, 55, 1564.

70. De Clercq, B.; Verpoort, F. Catal. Lett. 2002, 83, 9.

71. De Clercq, B.; Lefebvre, F.; Verpoort, F. Appl. Catal. A-Gen. 2003, 247.

72. De Clercq, B.; Lefebvre, F.; Verpoort, F. New J. Chem. 2002, 26, 1201. 